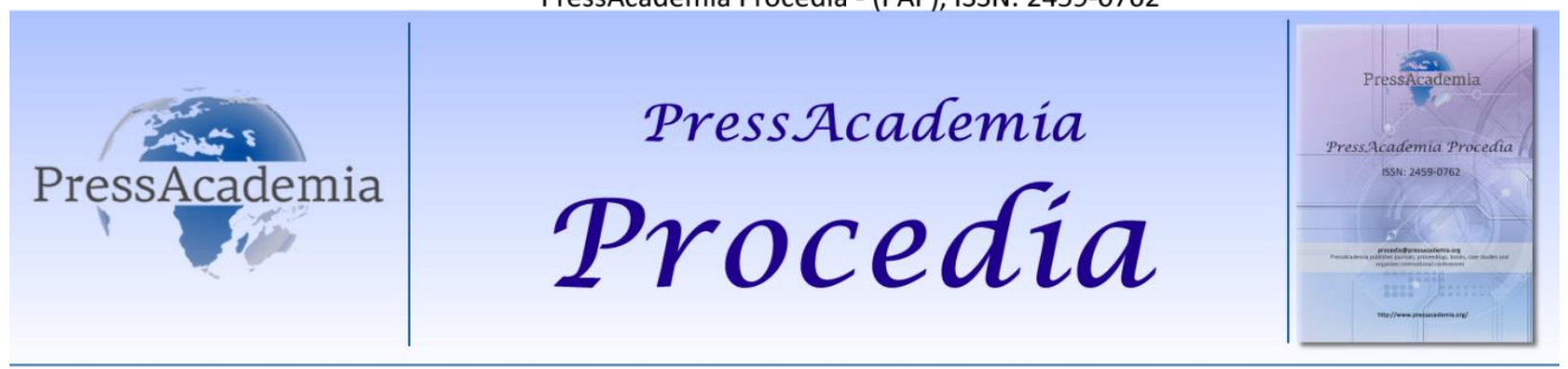

2nd World Conference on Technology, Innovation and Entrepreneurship,

May 12-14, 2017, Istanbul, Turkey. Edited by Sefer Şener

\title{
TECHNOLOGY MANAGEMENT IN GLOBAL COMPETITION AND COMPETITIVE ADVANTAGE
}

\author{
DOI: 10.17261/Pressacademia.2017.549 \\ PAP-WCTIE-V.4-2017(41)-p.313-318
}

Deniz Dilara Dereli ${ }^{1}$

${ }^{1}$ Istanbul Kültür University, d.dereli@iku.edu.tr

\begin{abstract}
Technology is a major factor for success in the global competitive environment. In today's world, by technological development, competition become more intense and new opportunities arise. Obtaining an advantageous position in the global competitive environment depends on satisfying consumer demands with best quality at an affordable cost. However, achieving and maintaining competitive advantage is not only possible with low cost and high efficiency but also with right technology management. Meeting the changing needs and demands, ensuring competitive advantage and realizing economic growth depends on following technological developments and adapting new technologies to production activities and processes. In this context, it is necessary to understand the relationship between technology and competition, form necessary strategies, realize research and development activities for new technologies, make necessary investments and carry out the process of technology management. Technology management becomes essential for economic growth and sustainability of companies. This study aims to evaluate the impact on competitive advantage of technology management by putting out the importance of technology management.
\end{abstract}

Keywords: Technology managemet, competition, growth

JEL Codes: O32; F43

\section{INTRODUCTION}

In global competition technology is an important element for companies. Developing and managing technology lead to achieve and maintain competitiveness and improve economic performance and growth. Meeting today's changing market needs is only possible by forming compatible strategies on the axis of technology and effective technology management. Today the most effective variable that create difference is technology. it is not only enough to have the technology alone, but also it is important to manage it as a process. In order to use technology as an element of competition and development, companies look for ways to have the knowledge and to use the decision-making mechanisms more effective. Especially the intense competition and high quality expectations of globalization have led organizational leaders to focus on the development of product and process technologies. So that firms and institutions are being reshaped in order not to lag behind the change in technology. To stand against global competition, it is crucial to be ready to changing market needs and to plan technology development activities depending on these changes (Çakmak et al., 2012). Technology comes forward when it comes to produce the products and services with less source, at lower costs, in higher qualities and more benificial. While struggling in today's competitive environment, technology will carry the companies further by giving the chance to create more economic value than their competitors. Therefore managing the technology is an important issue for companies in global competition. While the level of technology form the competition power of companies, at the same time it shows the competition power of countires. In this context, the acquisition, establishment and operation of technology and the R\&D activities are gaining importance in the companies and these activities lead to technology management. Having technological improvements and technological innovations are the most powerful weapons ever. R \& $D$ activities and technology development investments are long-term profitable and qualified investments. For the provision of technology; developing product and process improvements by internal R \& D activities, transferring technology, using existing technology options must be emphasized. Both companies and countries need to form and apply the best strategy management in order to compete in international competition (ileri and Horasan, 2010). Therefore, how to manage technology has become an important issue in the past few decades, and the technology management community has 
developed a wide range of methodologies and applications for both academic research and practical applications. In addition, technology management has attracted much effort to explore its nature, concepts, frameworks, architectures, theories, systems, models, tools, functions, and real world implementations in order to demonstrate technology management methodologies and their applications (Liao, 2005).

\section{TECHNOLOGY}

The Word "technology" is formed by the combination of the words "technicos" (to operate technically, systematically and planned) and "logia" (words, discourses, direct word). In terms of word meaning, it means systematic and planned way of doing business or art. In daily life in general, technology is identified by a physical element or a tool; an electronic device, a transistor, or a gear is perceived as technology alone. But technology should be understood as the totality of useful information to produce useful products and to design new products. This information can be either a physical output (product) or a non-physical output (software, process, service). In any case, technology is a valuable and dynamic asset. Technology changes and evolves depending on changing requirements and increasing knowledge. Technology should be considered as an economic value. It allows products and services to be produced in higher quantities, better quality, more beneficial, with less resource and at lower costs. Society want to use technology as an element of competition and development. Thus, technology spreads, learns and continually evolves with new information (Çakmak et al., 2012). Technology has an impact on the economy worldwide. The first and most obvious example of this impact is Industrial Revolution. By the technological changes that took place in America over time, the effects of technology on production became even more clear. In this way, the efficiency of technology including social structures has come out and technology has become the central theme of the production process. In historical process there has been three types of relation between technology and society; social needs, resources of society and social environment (Afşar et al., 2016).

In general, technology development ability is expected to provide better growth performance and increase international competitiveness. Activities that have technologically faster product and process innovations, create a rapidly growing demand structure. The most dynamic products in world trade contain complex and rapidly changing technologies. At the enterance of new competitors into markets, technology intense activities face less attacks when compared with low technological activities in terms of scale, quality and technology requirements. Technology intense activities contribute to the speed of the development of some skills and lead to arise in the quality of these skills. Such activities have high opportunities and learning potentials necessary for the continuous application of science to technology. Skills in technology intense activities are more adaptable to technology and market trends and thus can respond more flexibly to changing competition conditions, offer wider externalities to the national technological system and other activities (Bayraktutan and Bıdırlı, 2016). Not to lose the technological competitive advantage that is gained by investing heavily in technology development efforts, countries have been forced to spread the products of these technologies around the world. When it comes to the dynamics of the technological development process, the development of new technologies can only be achieved through the sale of existing ones and the provision of a suitable economic and socio-cultural environment (Karadal and Türk, 2008).

\section{TECHNOLOGY-COMPETITION RELATION}

Technology is a major factor in long-term success or failure. New technologies create new markets or substitutions in existing markets, ignoring the existing technologies and their products, services and production processes (Betz, 1994). Technology differentiates the created value and competiton becomes more intense because of the changing competition conditions by technological developments and their implementations. Adaptable new technologies leads increasing competition power, competition power leads increasing profit, increased profit leads creativity. When considered together with the concept of competition, creativity also includes the ability to develop technologies that are accepted by the market and to be in market in time. The main determinant of competitiveness is R\&D and innovation-driven high and sustainable productivity growth. Technological innovations can lead to changes in competition, changes in product and process and changes in the markets. A global competitive strategy, qualified labour force, innovative, fast and efficient activities are the main components of competition power (Zerenler et al., 2007). Michael Porter's value chain plays an important role in examining and understanding the relationship between technology and competition. Accordingly, an enterprise consists of many activities such as designing, producing, marketing, distributing and supporting. All activities can be demonstrated by using a value chain. The value chain and its functions are the reflections of history, strategy of an enterprise and implementation of its strategy. The differences in value chains among the competitors are key points for competitive advantage. The value chain is a useful tool in explaining the relationship between technology and competition, because the enterprise, defined as a set of activities, is also a set of technologies. Technological change will also have an effect on competition because of the influence of technology on all value activities of an enterprise. Every value activity benefit from some technologies to integrate material and human resources and to produce output (Akın, 2001). 
In order for technology to be able to influence competitive advantage, it needs to play an important role in determining the relative cost or position of differentiation. Technology is involved in all value activities and connect them, and it can affect competitive advantage by influencing or changing other factors related to cost and differentiation, as well as its strong effects on both cost and diversification. Technological progress can make it easier to reach scale economies, or it can make it insignificant by providing flexibility (Akın, 2001). Because of the increasing competition in global markets, quality become the main issue in producing goods and services. It is necessary to use adequate and appropriate technology to achieve high quality level in goods and services and to make quality differentiation. In this context, technology is the most important factor determining quality. Intensification of competition leads to technological development. Depending on this situation, some developing technologies cause new market opportunities, and organizations continue to produce new goods and services to meet the increasing consumer demands. Also more advanced technologies come out with the usage of new technologies by other organizations. Technology management which predicts change, is the locomotive of transformation (Tekin et al., 2003). If the technology is managed properly, it is a competitive advantage for the company. If a firm has the ability to create more economic value than its competitors, it can be said to have competitive advantage. Technology is a very important resource to grow this economic value (Çakmak et al., 2012).

\section{TECHNOLOGY MANAGEMENT AND COMPETTIVE ADVANTAGE}

There has been increased interest in the 1980s among management scholars, consultants, and practitioners in the role of technology in such matters as corporate strategy, operations management, global competition. However, it must be put in a proper historical perspective. Technology became an explicit element in management practice and strategy at the end of the 19th century with the growth of large chemical and electrical companies, particularly in Germany and the U.S. Indeed, the industrial R\&D laboratories central to this growth can be seen as part of the functional and professional specialization that defines much of modern management practice. Even before World War I, companies in these and other industries had extensive networks of external technological contacts, competed globally, and formed strategic alliances, often as part of world cartels (Pavitt, 1990). Technology management is a field that explores and expresses technology as a company resource that determines the strategic and operational capabilities of companies while designing and producing products and services for the highest level of customer satisfaction, productivity, profitability and competitiveness (Ünsal, 2009, 169). It is the planning, development and implementation of the technology needed to form the strategic and tactical goals of an organization. It can also be defined as the establishment of the link between technical expertise and management and can also be defined as all activities for technology creation, procurement and development, such as technology transfer, design, production, marketing (Sarıhan, 1998). Çetindamar et al. (2006) define technology management activities as technology utilization, knowledge management, technology procurement, technology management, technology integration, technology protection (patenet / license), technology transfer, technology planning and forecasting, technology strategy, technology evaluation, technology commercialization and marketing (Ünsay, 2009).

The success of technology management depends on several factors (Akolaş, 2016):

- Decisions on technological innovation should be accepted by the management and their participation in decisions should be ensured,

- Equal time and energy must be spent at every stage of technology management,

- A vision must be set up for the technology infrastructure to compete long term,

- Infrastructure should be connected with quality and continuous improvement of quality should be ensured,

- Business management should not regard technology as a cost element and should accept technology-related expenditures as an investment,

- Benefits of technology should be measured using appropriate standards, not accepted standards,

- The social, educational, political and economic forces that influence the managerial decision-making process should tried to be changed by technology management.

- Technology management should be built in a structure that will follow the new organizational approach and the objectives of this approach,

- In order to adopt all technological developments and new information within the organization, appropriate organizations should be established both inside and outside the organization and production and operation strategies must be fully harmonized,

- Technology should be used as a positive force in the change of the business and labor must be prepared for changes,

- $\quad$ Expert staff should be employed in the use of technology, existing staff should be trained or skilled labor should be used. 
In order for the technology management process to be conducted in a healthy manner, some strategic decisions are needed. Firstly the strategic technological planning-involving the integration of the technology plan with the company strategy- including strengths and weaknesses, internal and external factors that affect the company's technological power, procurement and supply channels, macro-technological planning, product, production decision of product, service and process with existing sources, usage of resources for new products has to be made. Next, the technological forecasting in which subjects as investmet forecast, technology tracing, suitiable product selection for market needs, ideas for competitive advantage are evaluated should be done. In the same way, R\&D activities should be carried out, R\&D structuring must take place including the identification of the needs, planning, organizing, projecting and the establishment of equipped R\&D team. In addition, patent, trademark registration and commercialization should be carried out. Finally, the marketing of technology which includes determination of market strategy, implementation of promotional activities and organization of technical service, has to be one of the strategic decisions (Sarıhan, 1998). With proper technology management, it is possible to obtain feedback on the related issues, understand the importance of the change, determine the problems quickly and solve them, maintain team work, carry out simultaneous engineering applications, eliminate unnecessary operations, plan the transition to automation gradually, give decisions by consediring the risks in new projects, establish a section that will adapt to the new technology and give the necessary technical support, create needed time for the realize the projects, grasp the importance of the individuals in project success and sustain advanced technology trainings of the employees (Tekin et al., 2003).

To use the technology as a source of competitive advantage, the companies must link and align their technology strategy with their operational activities such as marketing, human resources, production and investments. In the context of technology management, basically 5 actions have been defined so that the technology strategy can be created and aligned with the company's operational activities (Çakmak et al., 2012):

- SME's Monitoring and Identification Action of Existing Technologies: It is the action of determining critical information for the company by the identification of emerging or existing technologies and collecting, analyzing and evaluating of information on these technologies. There are many methods and tools that SMEs can use to monitor technology. Even existing processes, customer-supplier relationships, and marketing efforts can be monitored and identified. Routine activities such as marketing, human resources, supplier relationships, are activities that can be intertwined with the identification action of technologies.

- Technology Selection Action of SMEs for Competitive Advantage: It is the process of identifying and selecting critical technologies, taking into account the SME's strategic goals and priorities among the identified technologies. In this process, company's business strategies and technology strategies are combined and considered together. The selection criteria, possibilities and constraints that stand out within the business strategy of SME, play an important role in the evaluation of the related technologies.

- Procurement Action of Selected Technology: It is the action that encompasses the procurements as well as the decisions of the SME about how to have the needed technologies and to manage the acquisition process. Technology procurement includes the analysis and acquistion of necessary tools for the decisions such as developing technology by coorperation or by SME's own possibilities. A number of SMEs' operational activities, such as finance creation, human resource planning, business partnership development, are also involved in technology procurement.

- Usage or Utilization Action of the Acquired Technology: It is the action that includes the commercialization of the technology acquired by the company to achieve the expected benefit by using the technology as an input of the product or service. Within this context, SME's marketing, human resource planning and production activities are closely related to the method and planning of utilazing from technology.

- Conservation Action: Retention of hidden values in commercialized or non-ommercialized technology in various ways. Protection may be in the framework of intellectual property rights, or it may be through human resources planning. The important point is how these actions, which are generally accepted in the technology management literature, will be implemented and how they will be aligned with the company's activities. The most important issue to be emphasized is that technology management activities are not sequential business or step sequences but complementary actions that have input-output relation to each other. When technology management activities are recognized and implemented individually by the organization, it can be seen that some of the actions have come forward in a certain period of time, some have been implemented less and others have never been implemented in a certain time period. This is a natural result. For instance, the act of protecting technology may not be an activity that is important in an organization that focuses on the process of technology selection for a while. In the later stages of technology selection, protection action will come to the agenda and be 
implemented. For this reason, it should be considered how to protect the selected technology during technology selection. In this respect, ensuring coordination between activities will be achieved by first understanding the technology management activities one by one and then considering them holistically.

Developed technological strategy has great importance in ensuring competitive advantage. There are different strategies that can be pursued in this regard. In aggressive strategy, the goal is to develop a new product or process before the opponents and seize the market. For this purpose, it is necessary to follow technological developments closely, provide information flow, increase the risk taking ability of managers and employees, and form a flexible and learning organization structure. In the oppourtunity monitoring strategy, competitors follow and benefit from each other's weaknesses. In the defense strategy, companies try to get a share from the market by correcting the mistakes of competitor's products or by adding new functions to the product. The copycat strategy is a strategy in which the innovative company is imitated and the costs are minimized. In a dependent strategy, a company works like a satellite or a sub-organization of a strong company and changes in product specifications and services are made, if it is asked by the customer. In the traditional strategy, enterprises do not make R \& D but make design changes. (Sarıhan, 1998).

\section{CONCLUSION}

Technology is the key resource for long-term success of companies and countries. Making difference in competition depends on technological abilities. The planning, development and implementation of technological capabilities reconstruct the organizations. By the usage of new technologies, new markets are created and competition becomes more intense. The success of the companies in global competition will determine the growth and international competitiveness of the countries. In the global competitive environment, technology is required to provide quality improvement and to make a difference in the production of goods and services. In this respect, the determination and procurement of necessary technology and its usage in production processes are expected, so that the competitiveness and profitability both increase. However, it is necessary to manage the processes properly, which includes the determination of needs and harmonized technologies, the creation or transfer of necessary technology and its preservation, evaluation and commercialization. Some strategic decisions should be taken and the technology strategies should be aligned with the operational activities of the companies. Increasing the competitiveness of companies and countries in the intense and dynamic competitive environment depends on choosing the right technologies, making relevant investments and adapting the technology to organizational strategies. Companies have to follow technological developments closely and adopt them to their own systems. In addition, training of the employees and their adaptation to new technologies are required. In this context, resources need to be directed to appropriate technologies and the technology management process must be managed successfully. Technology management is crucial for companies in global competitive environment. By the creation or transfer of new technologies, and their usage in stages such as designing, production, distribution, marketing, competitive advantage and sustainable growth in productivity and quality can be achieved.

\section{REFERENCES}

Afşar, B., Ağcakaya, S., Öğrekçi, S. 2016, "Yeni Ekonomide Teknolojinin İşletme Yönetimi ve Girişimcilik Üzerindeki Dönüştürücü Etkileri" Elektronik Sosyal Bilimler Dergisi, vol. 15, no.18, pp. 752-762.

Akın, H.B. 2001, Yeni Ekonomi Strateji, Rekabet, Teknoloji Yönetimi, Konya, Çizgi Kitapevi.

Akolaş, D.A. 2016, "Teknoloji Yönetimi ve Teknoloji Yönetim Süreci”, Akdeniz Üniversitesi Yayını, vol. 1, no. 2, pp. 203-218.

Bayraktutan, Y., Bıdırlı, H. 2016, "Teknoloji ve Rekabetçilik: Temel Kavramlar ve Endeksler Bağlamında Bir Değerlendirme", Akademik Araştırmalar ve Çalışmalar Dergisi, vol. 8, no. 14, pp. 1-24.

Bets, F. 1994, Strategic Technology Management, McGraw-Hill International Editions.

Çakmak, T., Kılıç, A., Tunçay, A. 2012, Teknoloji Yönetimi Kılavuzu, İstanbul Sanayi Odası Yayını.

Çetindamar, D., Can, Ö., Pala, O. 2006, "Technology Management Activities and Tools: The Practice in Turkey", PICMET 2006 Proceedings, pp. 92-98.

İleri, H., Horasan, A. 2010, "Küresel Rekabet Ortamında İşletmelerin Teknoloji ve Ar-ge Yönetimlerinin Rekabete Etkileri Üzerine Bir Uygulama”, Selçuk Üniversitesi Sosyal Bilimler Meslek Yüksek Okulu Dergisi, vol. 13, no. 1-2, pp. 171-189.

Karadal, F., Türk. M. 2008, "İ̧sletmelerde Teknoloji Yönetiminin Geleceği”, Niğde Üniversitesi iỉBF Dergisi, vol. 1, no. 1, pp. 59-71. 
Liao, S. 2005, "Technology Management Metodologies and Applications A Litreature Review from 1995 to 2003", Technovation, no. 25, pp. 381-393.

Pavitt, K. 1990, "What We Know About the Strategic Management of Technology", California Management Review, 32/3, 17-26.

Sarıhan, i.H. 1998, "Rekabette Başarının Yolu Teknoloji Yönetimi”, Gebze: Desnet Yayınları.

Tekin, M., Güleş, H.K., Öğüt, A. 2003, ‘Değişim Çağında Teknoloji Yönetimi, Ankara, Nobel Yayın Dağıtım.

Zerenler, M., Türker, N., Şahin, S. 2007, “ Küresel Teknoloji, Araştırma-Geliştirme(Ar-ge) ve Yenilik iliş̧kisi, Selçuk Üniversitesi Sosyal Bilimler Enstitüsü Dergisi, no. 17, pp. 653-667. 